\title{
PENGELOLAAN POLUSI UDARA DAN SUARA DI LABORATORIUM OTOMOTIF JURUSAN TEKNIK MESIN
}

\author{
(THE AIR POLLUTION AND SOUND MANAGEMENT \\ OF AUTOMOTIVE MECHANICAL ENGINEERING LABORATORY)
}

\author{
Murdani \\ Fakultas Teknik Universitas Negeri Semarang \\ Sekaran, Gunung Pati, Kota Semarang, Jawa Tengah \\ e-mail:memurdani@yahoo.com
}

\begin{abstract}
Abstrak
Penelitian ini bertujuan untuk mengetahui: (1) seberapa besar penurunan polusi suara setelah menggunakan ekstra muffler di laboratorium otomotif teknik mesin, dan (2) seberapa besar penurunan polusi udara setelah penggunaan heater reactor di laboratorium otomotif teknik mesin. Metode penelitian yang digunakan adalah penelitian eksperimen untuk mengetahui tingkat temperatur yang efektif untuk menurunkan kadar polusi udara. Instrumen penelitian yang digunakan adalah: (1) gas analyzer dan smoke tester, (2) thermometer digital, (3) sound level meter. Hasil penelitian menunjukkan: penggunaan ekstra muffler di laboratorium otomotif Teknik Mesin Universitas Negeri Semarang mampu menurunkan tingkat kuat suara sebesar 9,46\%. Hal ini dibuktikan dengan perbandingan sebelum penggunaan alat ekstra muffler kuat suara yang terukur memiliki total nilai rata-rata $69,58 \mathrm{~dB}$, sedangkan setelah penggunaan alat total rata-rata kuat suara sebesar $63 \mathrm{~dB}$. Penggunaan electrical heater sebagai reaktor termal mampu menurukan kadar CO pada gas buang sebesar $19 \%$ dan $\mathrm{HC}$ sebesar 9,54\%. Hal ini dibuktikan dengan perbandingan pengukuran kadar emisi tanpa penggunaan kadar CO pada gas buang sebesar 1,888\% dan HC 262 ppm, dibandingkan dengan setelah penggunaan alat kadar CO sebesar 1,521\% dan $237 \mathrm{ppm}$.
\end{abstract}

Kata kunci: polusi udara, polusi suara, alat pengendali polusi

\begin{abstract}
This study was aimed at: (1) determining the reduction of noice pollution after using extra muffler, (2) calculating the reduction of air pollution after using heater reactor. The both of the research is conducted in automotive-mechanical engineering laboratory. This study was used experimental method. The instruments used in this study were: (1) gas analyzer and smoke tester, (2) digital thermometer, and (3) sound level meter. The results show that the use of extra muffler in the automotive-mechanical engineering laboratory of State University of Semarang is able to decrease of sound power of 9.46 percent. The mean of sound level before using extra muffler was $69.58 \mathrm{~dB}$, while the magnitude of the mean level after using extra muffler is $63 \mathrm{~dB}$. Electrical heater as a thermal reactor is able to reduct $\mathrm{CO}$ level of 1.888 percent and HC level of 262 percent in the exhaust gas. The measurement of $\mathrm{CO}$ level of exhaust gas emission
\end{abstract}


before using the reactor was 1.888 percent and $\mathrm{HC}$ level of $262 \mathrm{ppm}$, while $\mathrm{CO}$ level and $\mathrm{HC}$ level after using the reactor is 1.521 percent and $237 \mathrm{ppm}$.

Keywords: air-pollution, noise-pollution, extra muffler, heater reactor

\section{PENDAHULUAN}

Pada tahun 2012 Universitas Negeri Semarang (Unnes) telah mendeklarasikan dirinya sebagai universitas konservasi. PenerapankonservasiolehUniversitas Negeri Semarang secara resmidiaturdalamPeraturan Rektor Universitas Negeri Semarang nomor 27 tahun 2012 tentang tata kelola kampus berbasis konservasi. Pengelolaan kampus konservasi dilaksanakan dalam lingkup tujuh pilar konservasi yaitu: (1) konservasi keanekaragaman hayati, (2) arsitektur hijau dan sistem transportasi internal, (3) pengelolaan limbah, (4) kebijakan nirkertas, (5) energi bersih, (6) konservasi etika, seni dan budaya, dan (7) kaderisasi konservasi. Kepedulian Unnes terhadap lingkungan yang bersih dan sehat secara jelas tercantum dalam pilar konservasi yang menjadi arah pembangunan kampus Unnes.

Lingkungan yang bersih dan sehat merupakan dambaan bagi semua pihak, namun dengan perkembangan teknologi dan pengetahuan timbul beberapa dampak di antaranya adalah polusi. Kegiatan pembelajaran di dalam dunia teknik juga tidak bisa menghindari timbulnya polusi. Salah satu contoh adalah proses pembelajaran di laboratorium otomotif Teknik Mesin Unnes. Untuk memenuhi tuntutan kompetensi pada mata kuliah praktik otomotif, mahasiswa harus mampu menghidupkan mesin dari kondisi mati, hingga mengetahui fenomena kerja mesin pada putaran tinggi. Kondisi ini tentu menimbulkan polutan baik gas sisa pembuangan mesin yang berbahaya maupun suara mesin yang berderu kencang yang dapat mengganggu.

Polusi yang paling berbahaya yang dihasilkan oleh mesin motor adalah polusi udara dikarenakan zat-zat berbahaya bagi manusia yang dihasilkan dari sisa pembakaran di mesin dan dikeluarkan melalui gas buang. Dari hasil monitoring yang dilakukan oleh Nanny Kusminingrum (2008) menyatakan bahwa, tingkat pencemaran udara di kota-kota besar pulau Jawa dan pantura sudah hampir melampaui standar kualitas udara ambient khususnya untuk parameter oksida nitrogen, partikel, dan hidrokarbon. Massachusetts Institut Technology (MIT) mengungkapkan bahwa polusi udara memicu 200.000 kematian dini setiap tahun. Kondisi tersebut semakin memerlukan perhatian lebih dikarenakan letak laboratorium otomotif ini terletak 
didekat ruang Tata Usaha, ruang kuliah teori dan Ruang Ketua Program Studi di jurusan teknik mesin. Polusi yang dihasilkan oleh mesin di laboratorium otomotif tersebut bisa sangat mengganggu dan berbahaya bagi civitas akademika di jurusan Teknik Mesin.

Berdasarkan uraian permasalahan di atas, semakin memperkuat kebutuhan akan pentingnya pengelolaan polusi di lingkungan sekitar kampus. Universitas Negeri Semarang sebagai universitas konservasi telah memberikan langkah yang konkrit untuk menjalankan misi konservasi dan sangat peduli dengan pelestarian lingkungan. Demi mendukung misi konservasi untuk menciptakan lingkungan kampus Unnes yang sehat dan menciptakan aktivitas civitas akademika yang nyaman, semakin mempertegas akan pentingnya pengelolaan polusi di lingkungan kampus terutama lingkungan laboratorium otomotif teknik mesin.

Pencemaran suara adalah keadaan masuknya suara yang terlalu banyak sehingga mengganggu kenyamanan lingkungan manusia. Pencemaran suara cukup menjadi ancaman serius bagi kualitas lingkungan terutama di bagian suasana. Sumber pencemaran suara adalah kebisingan, yaitu bunyi atau suara yang dapat mengganggu dan merusak pendengaran manusia. Bunyi disebut bising apabila intensitasnya telah melampaui batas yaitu $50 \mathrm{~dB}$. Suara dengan intensitas tinggi, seperti yang dikeluarkan oleh banyak mesin industri, kendaraan bermotor, dan pesawat terbang bila berlangsung secara terus-menerus dalam jangka waktu yang lama dapat mengganggu kesehatan manusia, bahkan menyebabkan cacat pendengaran yang permanen. Dari hasil penelitian yang dilakukan oleh Nurul Hidayati (2007), menyimpulkan bahwa tingkat kebisingan akibat pengaruh arus lalu lintas pada zona pendidikan di wilayah Surakarta semua di atas ambang baku yang ditetapkan. Untuk di wilayah Jakarta, hasil penelitian yang dilakukan oleh Putra (2011) menyimpulkan bahwa tingkat kebisingan yang ada dalam kelas akibat pengaruh internal semua sudah melebihi batas ambang baku yang ditetapkan. Tingkat kebisingan yang diijinkan pada masing-masing kawasan berbeda-beda, seperti halnya pada lingkungan sekolah tingkat kebisingan yang diperbolehkan adalah $55 \mathrm{~dB}$. Dengan demikian perlu kiranya membuat alat pengelolaan suara dan udara yang dapat digunakan untuk mengelola kebisingan yang terjadi pada ruang praktik.

Pada mesin konvensional tidak ada sistem pengontrol gas buang mesin sehingga tingkat polusi yang dihasilkan cukup tinggi. Selain itu, kondisi knalpot media mesin di laboratorium otomotif juga tidak standar sehingga menimbulkan bunyi yang cukup keras sehingga dapat mengganggu proses 
pembelajaran di lingkungan kampus jurusan teknik mesin. Berdasarkan pengambilan data menggunakan sound meter tingkat kebisingan mesin di laboratorium saat satu mesin dihidupkan mencapai 75-80 dB saat putaran idle dan bisa bertambah lagi apabila putaran mesin dinaikkan. Kondisi ini tidak baik untuk proses pembelajaran yang menganjurkan tingkat kebisingannya sekitar $55 \mathrm{~dB}$. Suara bising dari mesin ini tidak hanya mengganggu proses pembelajaran, tetapi juga dapat mengganggu aktivitas civitas akademik di jurusan teknik mesin, mengingat lokasi laboratorium otomotif bersebelahan dengan ruang tata usaha, ruang ketua program studi dan kepala laboratorium di jurusan teknik mesin di lantai dua.

Kesepakatan para ahli mengemukakan bahwa batas toleransi untuk pemaparan bising selama 8 jam per hari, sebaiknya tidak melebihi ambang batas $85 \mathrm{dBA}$. Pemaparan kebisingan yang keras selalu di atas $85 \mathrm{dBA}$, dapat menyebabkan ketulian sementara. Biasanya ketulian akibat kebisingan terjadi tidak seketika sehingga pada awalnya tidak disadari oleh manusia. Baru setelah beberapa waktu terjadi keluhan kurang pendengaran yang sangat mengganggu dan dirasakan sangat merugikan. Pengaruh-pengaruh kebisingan selain terhadap alat pendengaran dirasakan oleh para pekerja yang terpapar kebisingan keras mengeluh tentang adanya rasa mual, lemas, stres, sakit kepala bahkan peningkatan tekanan darah. Apakah kebisingan dapat menyebabkan perubahan yang menetap seperti penyakit tekanan darah tinggi?. Nilai ambang batas kebisingan mengacu pada Keputusan Menteri Tenaga Kerja No. 5 1/KEPMEN/1999. Nilai ambang batas ini menggunakan patokan kebisingan ditempat kerja yang dapat diterima tenaga kerja tanpa mengakibatkan penyakit atau gangguan kesehatan dalam pekerjaannya sehari-hari untuk waktu tidak melebihi 8 jam sehari atau 40 jam seminggu.

Pencemaran udara adalah kehadiran satu atau lebih substansi fisik, kimia, atau biologi di atmosfer dalam jumlah yang dapat membahayakan kesehatan manusia, hewan, dan tumbuhan, mengganggu estetika dan kenyamanan, atau merusak properti. Pencemaran udara dapat ditimbulkan oleh sumber-sumber alami maupun kegiatan manusia. Beberapa definisi gangguan fisik seperti polusi suara, panas, radiasi atau polusi cahaya dianggap sebagai polusi udara. Sifat alami udara mengakibatkan dampak pencemaran udara dapat bersifat langsung dan lokal, regional, maupun global. Pencemaran udara di dalam ruangan dapat mempengaruhi kesehatan manusia sama buruknya dengan pencemaran udara di ruang terbuka.

Polusi udara yang ditimbulkan dari pelaksanaan praktik otomotif berasal dari sisa pembakaran mesin bensin. Polusi dari mesin bensin memiliki asap yang tidak 
pekat tetapi memberikan efek yang lebih berbahaya bagi kesehatan tubuh. Unsur yang berbahaya tersebut meliputi Karbon monoksida (CO2), Nitrogen Oksida $\left(\mathrm{NO}_{\mathrm{X}}\right)$, Hidro Karbon (HC). Polusi ini timbul dari efek pembakaran di ruang bakar mesin. Banyak penyebab yang menimbulkan polutan ini terjadi, salah satunya adalah pembakaran yang tidak sempurna. Proses pembakaran yang tidak sempurna ini tidak bisa dihindari, karena dalam pelaksanaan praktek otomotif oleh mahasiswa pasti akan mengakibatkan proses pembakaran mesin yang tidak sempurna. Sebagai solusi untuk permasalahan ini maka perlu pengelolaan polusi udara yang baik.

Substansi pencemar yang terdapat di udara dapat masuk ke dalam tubuh melalui sistem pernapasan. Jauhnya penetrasi zat pencemar ke dalam tubuh bergantung kepada jenis pencemar. Partikulat berukuran besar dapat tertahan di saluran pernapasan bagian atas, sedangkan partikulat berukuran kecil dan gas dapat mencapai paru-paru. Dari paru-paru, zat pencemar diserap oleh sistem peredaran darah dan menyebar ke seluruh tubuh. Dampak kesehatan yang paling umum dijumpai adalah ISNA (infeksi saluran napas atas), termasuk di antaranya, asma, bronkitis, dan gangguan pernapasan lainnya. Beberapa zat pencemar dikategorikan sebagai toksik dan karsinogenik. Menurut Toyota step 2, beberapa efek buruk yang ditimbulkan oleh gas karbon monoksida pada manusia: (1) akan bercampur dengan haemoglobin yang terdapat dalam darah menjadi karbon monoksida haemoglobin (CO-Hb), (2) bertambahnya $\mathrm{CO}-\mathrm{Hb}$, menyebabkan pengaliran oksigen dalam darah akan terhalang, dan (3) kadar CO-Hb 5\% dalam darah (dalam udara CO 40 ppm) maka akan menimbulkan keracunan dalam darah.

Salah satu solusi pengelolaan polusi udara yang bisa digunakan untuk mengatasi permasalahan di laboratorium otomotif adalah penggunaan blower dan long exhaust untuk membuang gas sisa hasil pembakaran ke luar ruangan. Solusi ini dirasa paling tepat karena tidak perlu merubah konstruksi bangunan yang ada, cukup menggunakan instalasi pipa pembuangan dan blower yang akan menghisap dan membuang gas sisa pembakaran.

Sejalan dengan misi konservasi, Universitas Negeri Semarang berusaha menciptakan lingkungan yang sehat dan bersih. Solusi penggunaan blower dan pipa untuk membuang gas sisa pembakaran cukup efektif untuk mengeluarkan polusi keluar ruangan, tetapi gas yang dikeluarkan masih memiliki zat-zat yang berbahaya sehingga perlu diciptakan pengelolaan polusi yang lebih baik dan efektif. Berbagai usaha telah dilakukan untuk mengontrol polusi $\mathrm{CO}$ di udara, beberapa cara yang dapat dilakukan antara lain: (1) modifikasi sistem pembakaran 
untuk mengurangi jumlah polutan yang terbentuk selama proses pembakaran berlangsung, (2) pengem-bangan sistem pembuangan sehingga polutan yang berbahaya dapat dirubah menjadi lebih aman, dan (3) pengembangan subtitusi bahan bakar yang menghasilkan konsentrasi polutan yang rendah selama proses pembakaran.

Salah satu cara yang dapat digunakan untuk mengelola polusi di laboratorium otomotif jurusan teknik mesin adalah dengan membuat sistem pembuangan untuk merubah polutan yang berbahaya menjadi lebih aman. Cara ini dinilai paling efektif dikarenakan mesin yang digunakan dalam pelaksanaan praktik di laboratorium otomotif terdiri dari berbagai jenis mesin sehingga memodifikasi sistem pembakaran tidak mungkin untuk dilakukan. Selain itu, pengenbangan subtitusi bahan bakar juga masih sulit untuk dilakukan karena bahan bakar alternatif memiliki harga yang lebih mahal sehingga tidak tepat untuk digunakan dalam pembelajaran yang membutuhkan konsumsi bahan bakar dalam jumlah yang besar.

Usaha masih terus dilakukan untuk mengembangkan suatu reactor exhaust thermal supaya dapat mengatasi emisi pembakaran mesin bensin yaitu hidro karbon (HC) dan karbon monoksida (CO). Reactor exhaust thermal dapat dibuat dengan memanfaatkan panas dari gas sisa pembakaran untuk memanasi ruangan ruangan bersuhu tinggi reaktor, tetapi cara ini akan membutuhkan waktu yang lebih lama dan tidak efektif karena jumlah engine stand yang ada di jurusan teknik mesin cukup banyak.

\section{METODE PENELITIAN}

Metode penelitian yang digunakan di dalam penelitian ini adalah penelitian eksperimen. Penelitian ini bermula dari permasalahan polusi udara dan suara yang tidak terkendali dengan baik di laboratorium otomotif. Penelitian ini berfokus untuk mengembangkan alat yang mampu mengurangi polusi tersebut sehingga dapat menciptakan lingkungan yang bersih dan sehat untuk mendukung kenyamanan dalam proses pembelajaran selaras dengan misi Unnes konservasi.

Luaran dari penelitian ini adalah dihasilkannya alat pengelola polusi dari mesin baik polusi udara maupun polusi suara untuk menciptakan suasana kampus yang tidak bising dan menciptakan udara yang besih dan sehat di sekitar kampus. Secara konsep, alat yang dihasilkan dari penelitian ini diilustrasikan melalui Gambar 1.

Penggunaan reaktor thermal yang digunakan untuk memanaskan udara akan memanfaatkan pemanas elektrik sehingga dapat ditentukan temperatur paling efektif untuk menurunkan kadar emisi gas buang. Desain alat penurun polusi udara dan suara terintegrasi menjadi satu. Bagian muffler 


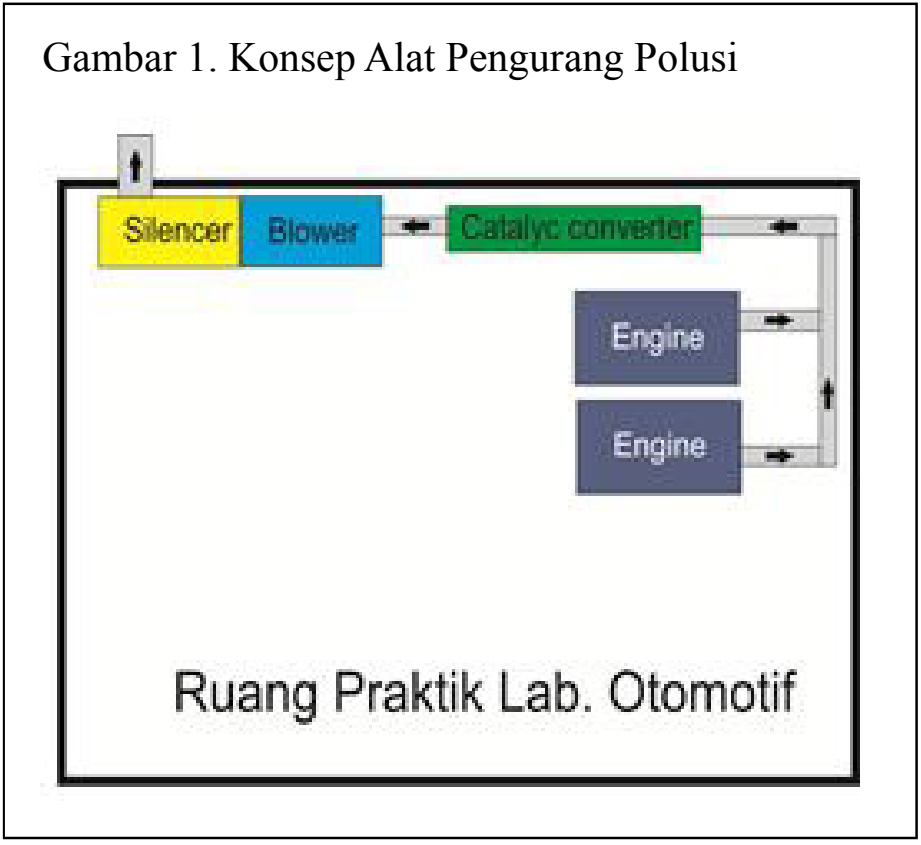

berfungsi untuk menunkan kuat suara yang dikeluarkan oleh knalpot. Lihat Gambar 2.

Selain itu, muffler juga berfungsi untuk menurunkan laju aliran gas sisa pembakaran. Heater bekerja berdasarkan aliran listrik yang diubah menjadi panas. Panas dari heater digunakan untuk memanaskan gas buang hasil pembakaran. Efek pemanasan heater menjadi lebih optimal karena laju aliran menjadi lambat setelah dihambat oleh muffler.

Penelitian ini bertujuan untuk mengurangi polusi udara dan suara di lingkungan jurusan teknik mesin Unnes. Tingkat kebisingan yang ideal bagi pembelajaran berada pada tingkat $55 \mathrm{~dB}$, hal ini pada kondisi lingkungan kelas. Pada kondisi pembelajaran di bengkel belum ada standar yang ditentukan. Peneliti berasumsi kondisi dilaboratorium teknik meisn dapat dipadankan dengan kondisi di perusahaan yang idealnya memiliki tingkat kebisingan 70 dB. Pencapaian pada pengelolaan polusi udara, di-sesuaikan dengan nilai ambang batas yang sudah ditetapkan oleh pemerintah. Keberhasilan dari penelitian ini dapat dilihat dari indikator berikut: (1) tingkat polusi udara yang dikeluarkan di pipa gas buang memiliki kadar CO 4,5\% dan HC 1200 ppm. (2) Tingkat polusi suara di laboratorium otomotif maksimum pada tingkat $70 \mathrm{~dB}$.

\section{HASIL DAN PEMBAHASAN}

Berdasarkan kajian teori, telah ditentukan pengukuran akan menggunakan titik sampling dikarenakan pengukuran 


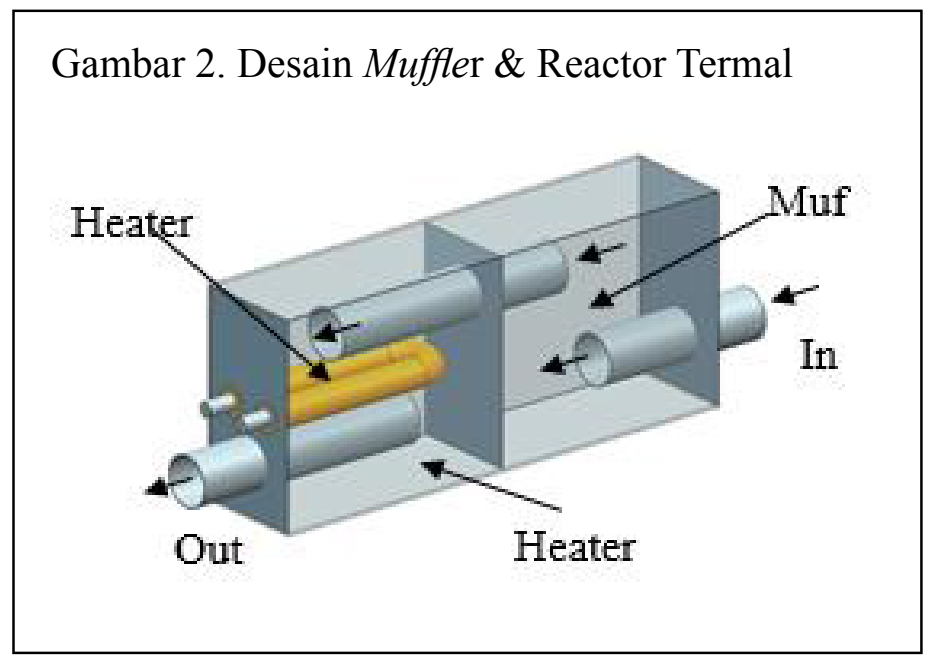

dilakukan pada beberapa titik strategis yang sudah ditentukan, yaitu: (1) titik A merupakan titik terdekat dengan sumber bunyi, jarak pengukuran kurang lebih satu meter, (2) titik B merupakan koridor di gedung E9 lantai dua, titik ini sering digunakan untuk memberikan teori kepada siswa dan pelaksanaan praktikum yang lain. Titik ini berjarak empat meter dari sumber bunyi, (3) titik $\mathrm{C}$ merupakan kantor tata usaha jurusan teknik mesin, titik ini berjarak sekitar delapan meter dari sumber bunyi, dan (4) titik D merupakan area sekitar ruang kaprodi PTO, PTM dan TMD3. Titik ini berjarak sekitar 12 meter dari sumber bunyi.

Pengukuran tingkat polusi suara dilakukan dengan menggunakan alat sound level meter di beberapa titik sampel yang sudah ditentukan yaitu pada empat titik tersebut. Alat ukur diletakkan pada posisi yang sama yaitu pada ketinggian satu meter dari lantai. Pengambilan data dilakukan pada variasi putaran mesin yang berbedabeda yaitu pada putaran $800 \mathrm{rpm}$, dan 2000 rpm. Kondisi ini mensimulasikan kondisi pembelajaran di laboratorium. Berdasarkan data yang sudah dikumpulkan menggunakan alat sound level meter, didapatkan hasil penurunan kuat suara pada putaran mesin $800 \mathrm{rpm}$ pada empat titik sampling dengan rata-rata $64,5 \mathrm{db}$ tanpa menggunakan alat dan $60,165 \mathrm{db}$ setelah menggunakan ekstra muffler. Pada putaran mesin 2000 rpm terjadi penurunan kuat suara pada empat titik sampling dengan nilai rata-rata 74,665 $\mathrm{db}$ tanpa menggunakan alat menjadi 65,835 $\mathrm{db}$ setelah menggunakan alat ekstra muffler. Berdasarkan data didapatkan hasil total penurunan kuat suara menggunakan ekstra muffler sebesar 9,46\%.

Pengukuran kadar polusi udara menggunakan alat gas analyzer. Alat ini mampu 
mengukur polutan yang berbahaya bagi manusia yaitu $\mathrm{CO}$ dan $\mathrm{HC}$. Selain itu alat ini juga dapat mengukur kadar $\mathrm{O} 2$ dan CO2 hasil pembakaran. Pengambilan data diambil menggunakan sampel engine stand yang digunakan pada praktik kelistrikan otomotif. Sampel engine diambil secara purposive. Data penelitian pada sampel diambil tiga kali untuk meminimalisasi kesalahan pengambilan data. Pengukuran polusi udara dilakukan pada kondisi mesin hidup seperti pada kondisi pelaksanaan praktik. Suhu gas buang yang mengalir dari mesin tanpa menggunakan reaktor thermal rata-rata sebesar $80^{\circ} \mathrm{C}$, pada penggunaan reaktor thermal, suhu aliran gas buang berkisar $160^{\circ} \mathrm{C}$. Grafik hasil pengujian kadar CO dapat dilihat pada Gambar 3.

Berdasarkan grafik tersebut dapat dilihat perbandingan kadar emisi tanpa menggunakan heater dan dengan menggunakan reaktor thermal. Terjadi penurunan kadar $\mathrm{CO}$ pada gas buang mesin dengan nilai rata-rata $1.888 \%$ sebelum menggunakan reaktor thermal menjadi $1,521 \%$ setelah menggunakan hetaer. Berdasarkan data tersebut didapatkan hasil bahwa penggunaan reaktor thermal elektrik mampu menurunkan kadar CO pada gas buang sebanyak 19\%.

Hasil pengujian kadar HC pada mesin dapat dilihat pada Gambar 4.

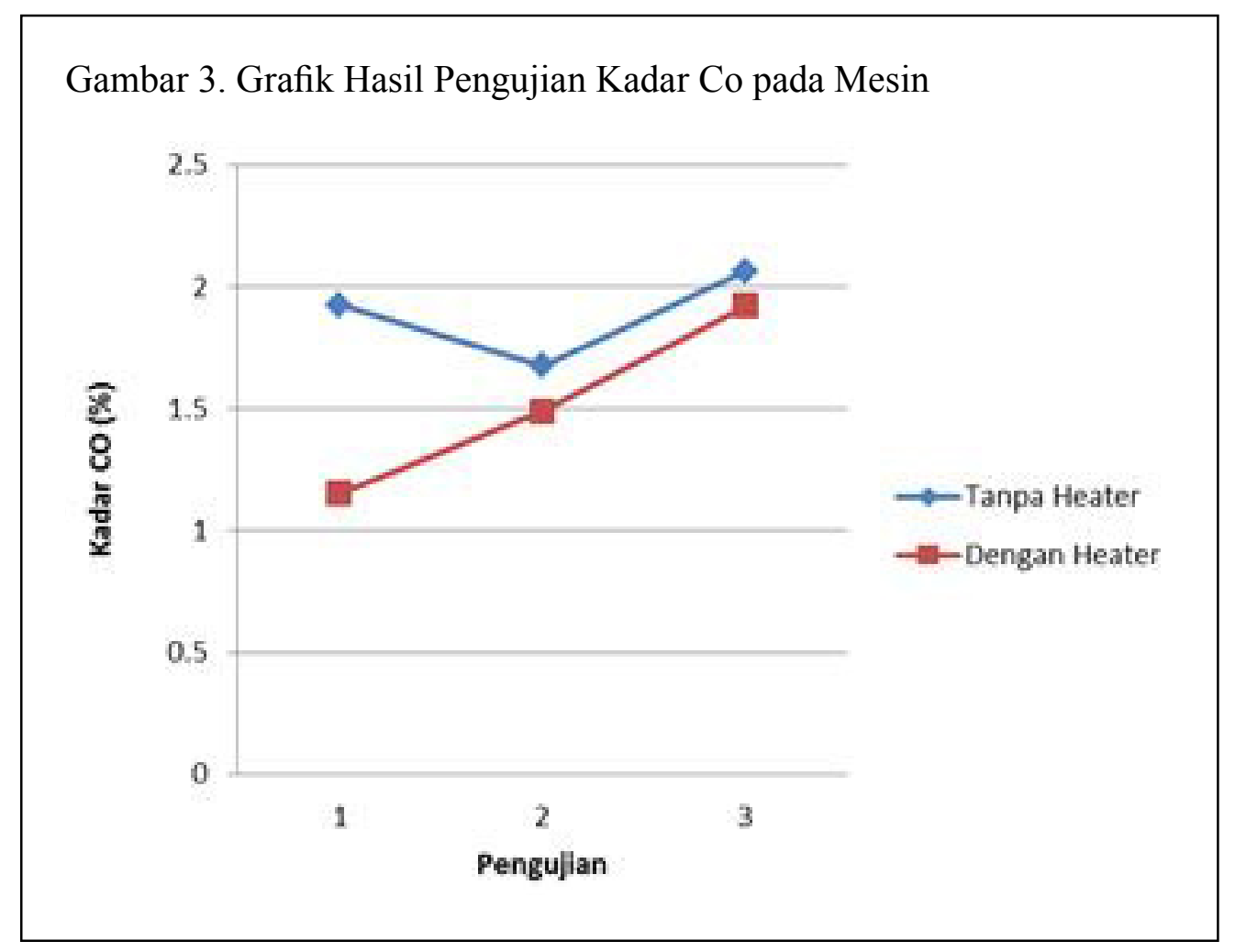




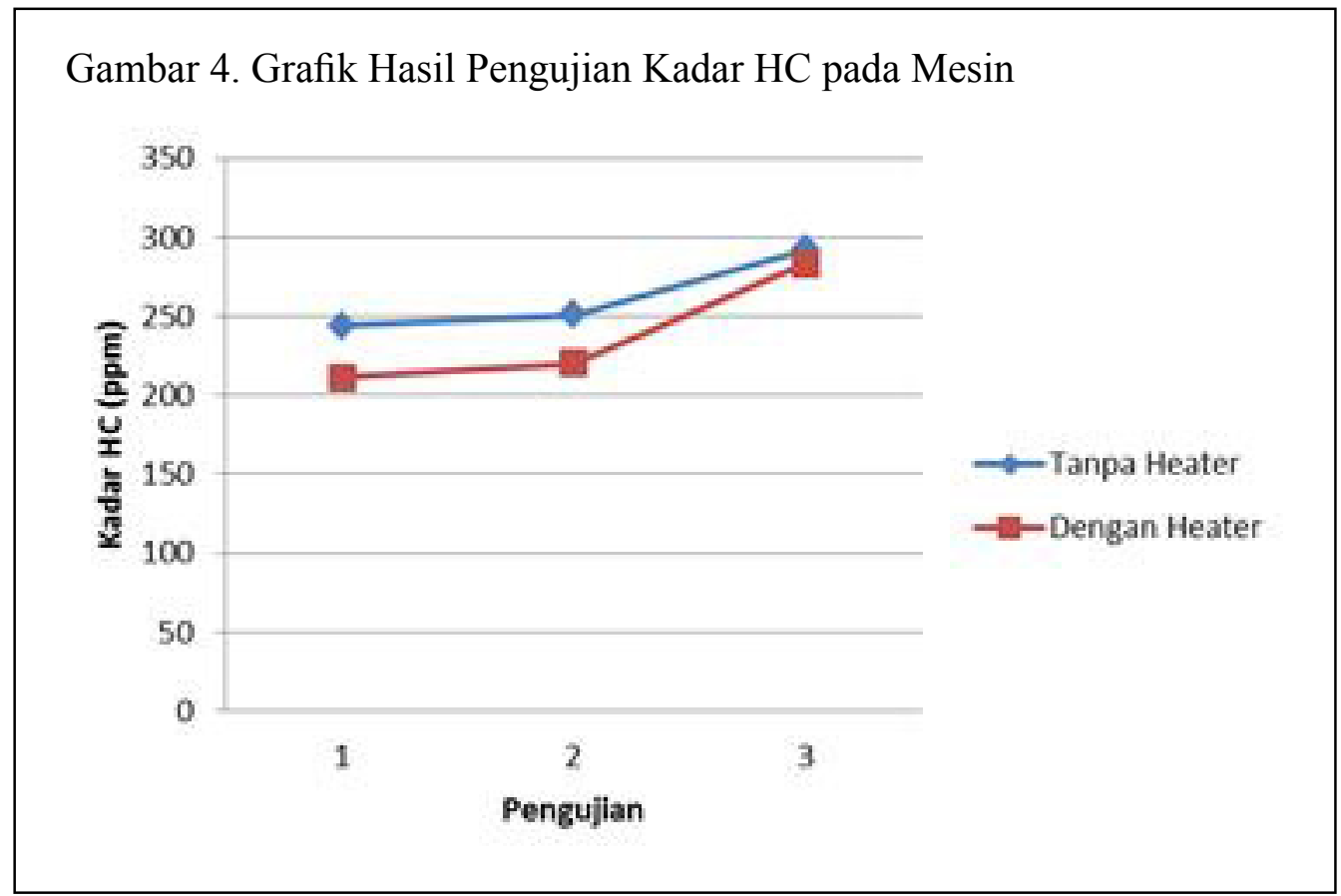

\begin{abstract}
Berdasarkan Gambar 4 dapat dilihat perbandingan kadar emisi $\mathrm{HC}$ tanpa menggunakan heater dan dengan menggunakan reaktor thermal. Terjadi penurunan kadar HC pada gas buang mesin dengan nilai rata-rata $262 \mathrm{ppm}$ sebelum menggunakan reaktor thermal menjadi 237 ppm setelah menggunakan heater. Berdasarkan data tersebut didapatkan hasil bahwa penggunaan elektrik reaktor thermal mampu menurunkan kadar $\mathrm{HC}$ pada gas buang kendaraan sebanyak 9,54\%.
\end{abstract}

\section{SIMPULAN}

Berdasarkan hasil pengumpulan dan analisis data yang telah dilakukan, kesimpulan yang didapatkan dari penelitian ini adalah: pertama, pengelolaan polusi udara menggunakan ekstra muffler di laboratorium otomotif Teknik Mesin Unnes mampu nenurunkan tingkat kuat suara sebesar 9,46\%. Hal ini dibuktikan dengan perbandingan sebelum penggunaan alat ekstra muffler kuat suara yang terukur memiliki total nilai ratarata $69.58 \mathrm{db}$, sedangkan setelah penggunaan alat total rata-rata kuat suara sebesar 63 db. Sesuai dengan keputusan Menteri Negara Lingkungan Hidup Nomor Kep. 48/ MENLH/11/1996 nilai $63 \mathrm{db}$ mendekati nilai ambang batas tingkat kebisingan di kawasan perkantoran yaitu sebesar $60 \mathrm{db}$. Kedua, pengelolaan polusi udara menggunakan electrical heater sebagai reaktor thermal mampu menurukan kadar $\mathrm{CO}$ pada gas buang sebesar $19 \%$ dan HC sebesar 9,54\%. Hal ini dibuktikan dengan perbandingan 
pengukuran kadar emisi tanpa penggunaan kadar CO pada gas buang sebesar $1.888 \%$ dan HC 262 ppm, dibandingkan dengan setelah penggunaan alat kadar $\mathrm{CO}$ sebesar $1.521 \%$ dan 237 ppm. Berdasarkan hasil yang diperoleh di atas alat yang digunakan dianggap cukup efektif untuk menurunkan kadar emisi gas buang kendaraan.

\section{DAFTAR PUSTAKA}

Keputusan Menteri Negara Lingkungan Hidup Nomor: KEP-48/MENLH/11/ 1996 tentang Baku Tingkat Kebisingan.

Peraturan Menteri Negara Lingkungan Hidup Nomor 04 Tahun 2009 tentang Ambang Batas Emisi Gas Buang Kendaraan Bermotor Tipe Baru.

Kusminingrum, N. (2008). Polusi udara akibat aktivitas kendaraan bermotor di
Pulau Jawa dan Bali. Bandung: Pusat Litbang Jalan dan Jembatan.

Hidayati, N. (2007). Pengaruh arus lalulintas terhadap kebisingan. Dinamika TEKNIK SIPIL Volume 7, Nomor 1, Januari 2007: 45-54.

Putra, P. A. (2011). Tingkat penyemaran udara kawasan sekolah berdasakan parameter total suspended partikulate dan kebisingan akibat kendaraan yang melintas (Skripsi Tidak Dipublikasikan). Fakultas Teknik UI, Jakarta.

http://konservasi.unnes.ac.id/?page_id=378

http://pplhselo.or.id/berita/polusi-cabut200000-nyawa-setiapnbsp.html

http://www.indonesian-publichealth. com $/ 2013 / 07 /$ kebisingan-dankesehatan.html 